\title{
Território e cafeicultura no Brasil: uma proposta de periodização
}

\author{
Samuel Frederico \\ Unesp \\ p. $73-101$
}

revista

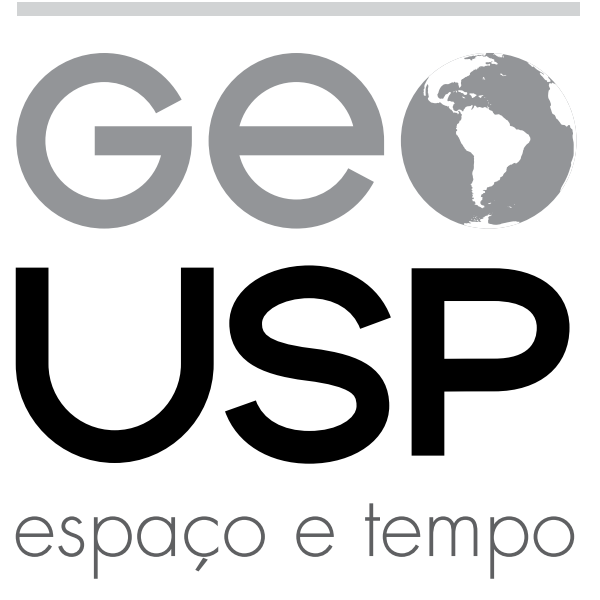

Volume $21 \bullet \mathrm{n}^{\circ} 1(2017)$

ISSN 2179-0892
Como citar este artigo:

FREDERICO, S. Território e cafeicultura no Brasil: uma proposta de periodização. Geousp - Espaço e Tempo (Online), v. 21, n. 1, p. 73-101, abril. 2017. ISSN 2179-0892.

Disponível em:

$<$ http://www.revistas.usp.br/geousp/article/view/98588>. doi: 10.11606/issn.2179-0892.geousp.2017.98588.

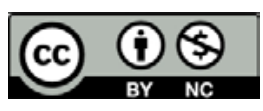

Este artigo está licenciado sob a Creative Commons Attribution 4.0 License. 


\title{
Território e cafeicultura no Brasil: uma proposta de periodização
}

\section{Resumo}

Este artigo propõe uma periodização da cafeicultura brasileira a partir da sucessão dos meios geográficos. Desde a mecanização do território, com a implantação das ferrovias, no século XIX, até a adoção mais recente de sistemas técnico-informacionais na agricultura, o café acompanhou de perto e em determinados momentos foi protagonista de transformações técnicas e políticas ocorridas na formação socioespacial brasileira nos últimos dois séculos. Assim, partindo de uma perspectiva territorial, este artigo pretende contribuir com as demais propostas de periodização de ordem econômica, política e normativa da cafeicultura brasileira disponível na literatura específica.

Palavras-chave: Periodização. Meios geográficos. Cafeicultura. Território brasileiro. Técnica.

\section{Territory and coffee production in Brazil}

\begin{abstract}
The article aims to propose a periodization of Brazilian coffee production from the succession of geographical environments. Since the mechanization of territory with the introduction of the railways in the nineteenth century to the most recent adoption of technical informational systems in agriculture, coffee production closely followed the transformations in the Brazilian socio-spatial formation in the last two centuries. Thus, based on a territorial perspective, this article intends to contribute to other proposals of periodization (economic, political and regulatory) of Brazilian coffee production available in the literature.
\end{abstract}

Keywords: Periodization. Geographical environment. Coffee production. Brazilian territory. Technique. 


\section{Introdução}

A cafeicultura brasileira completa neste início de século XXI seu bicentenário. Mais do que qualquer outra cultura, o café acompanhou de perto as consecutivas divisões territoriais do trabalho ao longo da sucessão e coexistência dos meios geográficos no território brasileiro (Santos, 1994, Santos; Silveira, 2001). A produção cafeeira foi uma das principais responsáveis pela mecanização do território, em meados do século XIX, assim como pela geração de divisas necessárias à industrialização (via substituição de importações) e à construção de grandes sistemas de engenharia entre a primeira e o início da segunda metade do século XX (Silva, S., 1986; Cano, 1998).

Muitas são as propostas de periodização da cafeicultura brasileira e mundial. A maioria delas refere-se aos ciclos econômicos do café, enfatizando as alterações na mão de obra empregada (escrava, colonato, trabalhadores temporários), na regulamentação do mercado nacional e internacional (maior ou menor intervencionismo estatal) e na produção em si do café (ciclos produtivos). Entre as principais periodizações, destacamse aquelas realizadas por: Delfim Netto (1981), referente aos ciclos dos preços internacionais do café; Bacha (1988), sobre as modificações do comércio internacional, da quantidade produzida e das políticas do governo brasileiro para a cafeicultura; Saes (1995), com relação à racionalidade econômica da regulamentação brasileira do mercado cafeeiro; Cano (1998), sobre a formação do complexo cafeeiro paulista; e Daviron e Ponte (2007), com base na regulação e governança da "cadeia de valor mundial" do café. Essas propostas de periodização são frutíferas para a compreensão das transformações de ordem econômica, política e normativa da produção cafeeira, mas, não priorizam a "materialidade e o dinamismo do território", isto é, a técnica, entendida de maneira indissociável "como formas de fazer e regular a vida" e também como "objetos geográficos" (Santos; Silveira, 2001, p. 26).

A evolução da cafeicultura brasileira, a partir de uma perspectiva geográfica, deve ser pensada paralelamente às mudanças no uso, organização e regulação do território brasileiro, ou seja, como a quantidade, a qualidade, a distribuição, a articulação, o uso e a normatização dos sistemas técnicos presentes no território autorizam e condicionam as ações (Ramos; Castillo, 2010). A sucessão dos meios geográficos permite uma periodização da formação do território brasileiro, tomada num sentido mais amplo, como as propostas por Santos e Silveira (2001) e Silveira (2007), assim como de suas situações geográficas particulares, como a modernização e a especialização regional da cafeicultura. A cada período, a indissociabilidade das variáveis de ordem técnica e política transformam o território como um todo, assim como a cafeicultura, e outras atividades produtivas, de forma particular.

Diante dessa proposta de método, este artigo subdivide a história da cafeicultura brasileira em quatro momentos: (a) um primeiro período, que vai do fim do século XVIII até as décadas de 1870-80, denominado Primórdios da Cafeicultura e o Meio Natural, que se caracteriza pela escassez de instrumentos técnicos e o domínio do "tempo lento" da natureza sobre as práticas produtivas, com a produção centrada no Vale do 
Paraíba (fluminense e paulista), Zona da Mata Mineira e sul do Espírito Santo. Nestas regiões, a prática de uma cafeicultura itinerante e fortemente predatória de recursos naturais (degradação dos solos) e o predomínio do trabalho escravo configuraram-se como importantes fatores para a decadência da produção. Trata-se de verdadeiras rugosidades territoriais (Santos, 1996), isto é, heranças físico-territoriais e sociopolíticas, que se mostraram irreversíveis para a continuidade daquela cafeicultura, mesmo com as tentativas de estimular a produção com a construção das primeiras estradas de ferro no início da segunda metade do século XIX. (b) O segundo período, denominado Mecanização da Cafeicultura e o Meio Técnico, vai do final do século XIX até as décadas de 1950-60, com a difusão das técnicas da máquina atreladas à produção e ao território e o deslocamento da produção do Vale do Paraíba para o Oeste Paulista e o norte paranaense. Esse pode ser considerado o período de apogeu da cafeicultura brasileira, em que a economia política cafeeira confundia-se com a economia e a política nacional. Decorrente do seu forte poder político-econômico, a expansão da produção cafeeira resultou em importantes transformações territoriais, particularmente no estado de São Paulo, com a criação de uma rede urbana interior, pela difusão dos sistemas de transporte e comunicação, o estímulo à industrialização, à urbanização e à imigração, o crescimento da mão de obra assalariada e a configuração da capital paulista como uma emergente metrópole nacional. Tratam-se dos momentos iniciais da conformação da Região Concentrada brasileira (Santos; Ribeiro, 1979; Santos; Silveira, 2001), com forte protagonismo da produção cafeeira. (c) O terceiro momento, denominado Cientifização da Cafeicultura e Meio Técnico-científico, caracteriza-se por importantes transformações de ordem técnica e normativa na cafeicultura brasileira e mundial. Trata-se, como sugere o próprio título, de um momento de intensa cientifização da cafeicultura com a difusão do paradigma da Revolução Verde, assim como de forte regulação do mercado internacional do café, por meio dos Acordos Internacionais do Café (AIC), que estipulavam os preços e as cotas de exportação e importação entre os países. No caso da cafeicultura brasileira, a internalização do novo padrão tecnológico resultou na substituição das variedades de plantas menos produtivas por cultivares mais eficientes e sensíveis ao uso de insumos químicos, assim como também foi um momento de forte regulação estatal, com a criação do Instituto Brasileiro do Café (IBC), responsável pela política de renovação dos cafezais, financiamento da produção, definição de preços e estoques. Sob as novas bases tecnológicas e normativas, a cafeicultura brasileira se expandiu principalmente em direção ao estado de Minas Gerais, transformando, respectivamente, o sul de Minas e o cerrado mineiro nas suas duas principais regiões produtoras, ao mesmo tempo em que diminuía a participação dos estados de São Paulo e Paraná (até então os principais produtores). (d) Por fim, o quarto período, denominado Cafeicultura Científica Globalizada e o Meio Técnico-científico-informacional, caracteriza-se pela emergência das técnicas da informação e pela influência das políticas e do ideário neoliberal na cafeicultura brasileira e mundial a partir da última década do século XX. Entre os principais eventos desse novo período ressalta-se a nova regulação do mercado cafeeiro, com o fim dos AIC e do IBC e 
o maior poder de ingerência das grandes corporações responsáveis pelo comércio do café verde e pela venda do café processado, assim como o aprimoramento e substituição dos sistemas técnicos herdados da Revolução Verde, por sistemas de objetos e ações com maior conteúdo em informação, como o desenvolvimento da biotecnologia, o uso de imagens de satélite e a formação de banco de dados digitais. No caso brasileiro, nenhuma outra região representa melhor a prática da cafeicultura científica globalizada do que o oeste da Bahia. Trata-se da mais recente região de expansão da cafeicultura, praticada em grandes propriedades e com o uso intensivo das novas técnicas da informação. Dessa forma, além desta introdução e das considerações finais, este artigo está subdividido nos quatro períodos anteriormente elencados.

\section{Primórdios da cafeicultura e o meio natural}

Ocafé é uma das principais heranças do "sistema colonial" brasileiro (Prado Jr., 1967), isto é, um produto primário surgido para atender às demandas do mercado internacional. De produto de luxo, no século XVIII, transformou-se em mercadoria de consumo de massa ao ser utilizado como estimulante pelos operários da indústria com a Revolução Industrial no século XIX (Topik, 2003). A grande expansão do comércio internacional do café no início daquele século deve-se à geopolítica dos EUA de busca de alternativas aos mercados controlados pela Inglaterra, sobretudo, do chá produzido pelas colônias britânicas. Com a crescente industrialização, os EUA se tornaram o maior mercado consumidor, transformando o café em uma das principais commodities internacionais, com preços estipulados pela bolsa de valores de Nova lorque e o comércio regulado por grandes exportadores e torrefadores estadunidenses e europeus (Topik, 2003; Daviron; Ponte, 2007; Daviron; Vagneron; 2011).

Nesse contexto, como já havia ocorrido em séculos anteriores com o açúcar e os metais preciosos, o território brasileiro se inseriu na divisão internacional do trabalho como grande fornecedor de matéria-prima. Como enfatiza Cano (2002), o território brasileiro detinha os requisitos necessários para a produção do café em larga escala, como: clima adequado (clima Tropical, com boa disponibilidade pluviométrica e temperaturas médias acima de $20 \circ \mathrm{C}$ ), disponibilidade de terras ociosas, mão de obra (escrava) e capital (decorrente da exploração mineral do final do século XVIII).

Agricultura tipicamente itinerante (Furtado, 1976), isto é, fortemente predatória de recursos naturais e carente de incorporação de novas terras para a manutenção da produtividade, o café foi introduzido no estado do Pará, na primeira metade do século XVIII, mas somente se consolidou definitivamente, quase um século depois, com a expansão das plantações fluminenses. Dos arredores da cidade do Rio de Janeiro, as plantações se expandiram para o interior do estado, ao longo do Vale do Paraíba, alcançando a Zona da Mata Mineira, o extremo leste do estado de São Paulo e o sul do Espírito Santo ainda nas primeiras décadas do século XIX (Taunay, 1945; Cano, 2002).

Tratava-se de uma cafeicultura que se difundia sobre um meio natural (Santos, 1996), isto é, com escassez de instrumentos técnicos, cujas condições naturais (clima, 
relevo, solos) se impunham como determinantes às ações humanas. A precariedade dos sistemas técnicos disponíveis e a falta de uma maior racionalização dos métodos produtivos promoviam o rápido esgotamento dos solos, exigindo a constante migração da atividade cafeeira. A retirada da cobertura vegetal, para o cultivo do cafeeiro a "pleno sol", ' associada ao plantio em linha reta nas encostas, não respeitando as curvas de nível, intensificava o processo erosivo, diminuindo a produtividade e a vida útil da planta (Prado Jr, 1967; Furtado; 1976).

Caio Prado Jr. (1967, p. 167), ao analisar a primeira fase da cafeicultura brasileira, demonstra como a um ciclo de "intensa e rápida prosperidade", seguia-se outro de "estagnação e decadência", devido ao esgotamento das "reservas naturais por um sistema de exploração descuidado e extensivo". Além do plantio irregular e da inexistência de adubação dos solos, os métodos de colheita e beneficiamento também eram bastante rudimentares. ${ }^{2}$

A colheita era realizada pelo método de "derriça", ainda predominante na maioria das regiões cafeeiras, que consiste na remoção manual dos galhos da planta de todos os tipos de grãos (maduros, verdes e secos), além de folhas e gravetos. Depois de colhido, os grãos eram beneficiados na própria fazenda. Segundo Argollo (2004, p. 59), desde o início, o beneficiamento do café foi considerado uma atividade "intrínseca ao sistema de produção".

A primeira etapa consistia na lavagem dos grãos para a retirada de impurezas, espalhando-os em seguida nos terreiros para secagem, onde permaneciam entre três a quatro semanas. As operações de pós-secagem, com o objetivo de "descascar" o café, eram realizadas por instrumentos em sua maioria de madeira (monjolo, carretão e engenho de pilões) movidos pela força animal ou hidráulica. ${ }^{3}$ As melhorias das técnicas produtivas ocorriam por tentativa e erro dos fazendeiros que "procuravam criar um modo de produzir adequado à realidade brasileira" (Argollo, 2004, p. 25). ${ }^{4}$

A manutenção do trabalho escravo, associada aos precários sistemas de transporte e de comunicação, dificultavam o aprofundamento da divisão social e territorial do trabalho. As grandes fazendas de café - cujas terras eram doadas (Sesmarias) pela Corte e/ou apropriadas pelos fazendeiros (grilagem) -, configuravam-se como unidades

1 No Brasil, diferentemente da maioria dos países produtores, o café é cultivado a pleno sol, sem nenhum tipo de cobertura vegetal. Prado Jr. (1967) atribui essa prática à herança do modelo de plantation (monoculturas escravistas produzidas em grande escala), adotado inicialmente no cultivo da cana-de-açúcar e posteriormente incorporado à cafeicultura.

2 Sobre as técnicas precárias de produção, ver Stein (1961), Valverde (1970) e Dean (1997).

3 Para uma análise detalhada e ilustrada do funcionamento das máquinas de beneficiamento do café, ver Argollo (2004).

4 Os métodos rudimentares de colheita, secagem e beneficiamento resultavam em um produto de má qualidade, o que tornou o nome das primeiras regiões produtoras do Rio de Janeiro e da Zona da Mata-MG sinônimo de café de qualidade inferior. Ainda hoje, os cafés denominados Rio e Rio Zona são considerados os de pior qualidade na classificação mais usada pelos exportadores brasileiros. 
praticamente autônomas, "autárquicas" (Argollo, 2004), "um mundo em miniatura", como relata Prado Jr. (1967). As ligações com o "exterior" eram estabelecidas pela cidade do Rio de Janeiro, que exercia o comando da produção, concentrando as funções de porto exportador e importador de manufaturas, centro financeiro e de comércio, e capital política (Valverde, 1970; Cano, 2002).

O transporte do café das fazendas ao porto era realizado por tropas de muares ou pelos cursos fluviais que corriam em direção à Baia de Guanabara. Araújo Filho (1956) afirma que as maiores lavouras, até a década de 1850, não se distanciavam muito mais do que $100 \mathrm{~km}$ do porto, devido aos precários meios de transporte, localizando-se preferencialmente nas margens dos principais rios.

Enquanto os fazendeiros ficavam restritos à fazenda, o grande responsável pelos fluxos comerciais e financeiros eram os comissários. Eles que estabeleciam a ligação entre a unidade produtiva e a cidade do Rio de Janeiro. No início, os comissários eram os representantes dos cafeicultores na venda do café e na compra de bens de consumo, principalmente manufaturados. Com o tempo, ganharam autonomia e passaram a fazer negócios por conta própria, constituindo as primeiras casas comissárias (Vieira, 2000). Além de comerciantes, com o crescimento das lavouras, entre as décadas de 1820-50, tornaram-se também fornecedores de crédito de investimento e custeio aos cafeicultores (Cano, 2002).

As firmas comissárias, localizadas nas cidades portuárias (Rio de Janeiro e posteriormente Santos), recebiamocaféem consignação, formavamas "ligas", misturando cafés de diferentes procedências, armazenavam o produto e posteriormente o vendiam às casas exportadoras. $O$ crédito ofertado ao fazendeiro era obtido diretamente nas casas bancárias, em nome da pessoa física do comissário, devido à inexistência de crédito agrícola. Os comissários conservaram certa importância no comércio e financiamento da produção, ainda que continuamente reduzida, até a crise de 1929 (Vieira, 2000).

A divisão territorial do trabalho atrelada à cafeicultura fluminense era estruturada pelas relações estabelecidas entre as unidades produtivas e a cidade portuária. As fazendas, itinerantes e localizadas no interior do estado do Rio de Janeiro e de estados circunvizinhos, eram praticamente autônomas, além de produzir o café, razão de sua existência, também produziam quase todos os demais produtos de que necessitavam, destacando-se a figura do fazendeiro, conhecido como "barão do café", e o uso da mão de obra escrava. ${ }^{5}$ A cidade do Rio de Janeiro, além do sistema portuário, concentrava também as casas comissárias, as poucas firmas exportadoras de café - em sua maioria de capital estrangeiro -, as firmas importadoras de manufaturas, os primeiros bancos, comércios diversos e pequenas unidades fabris de bens de consumo não duráveis.

Entre a "fazenda autárquica" e a cidade do Rio de Janeiro estabeleciam-se fluxos relativamente pouco diversificados. Em direção ao porto escoava-se o café e no sentido

5 Para mais detalhes sobre o funcionamento das fazendas escravocratas de café, ver Valverde (1970). 
inverso remetiam-se produtos manufaturados, informações e crédito para investimento e custeio da lavoura. Destacam-se também o tropeiro, os portos fluviais e seus armazéns - que entram em decadência com a implantação das ferrovias - e as unidades produtivas dedicadas à produção de gêneros alimentícios - que entram em crise com o progressivo aumento do preço dos escravos. ${ }^{6}$

A decadência da "cafeicultura fluminense" começa a ocorrer a partir da segunda metade do século XIX, momento em que se inicia a mecanização tanto da produção, com o desenvolvimento das primeiras máquinas de beneficiamento a vapor, quanto do território, com a construção das ferrovias, dos cabos telegráficos e com a modernização dos portos.

A mecanização do território entra em contradição com as relações de produção escravista. O mundo maquínico, derivado do capitalismo industrial e difundido pelo imperialismo europeu entra em descompasso histórico com as relações de servidão dominantes no Vale do Paraíba. Cano (2002) afirma que a dependência em relação ao trabalho escravo e a incapacidade de sua substituição foram os principais fatores da derrocada da cafeicultura do Vale do Paraíba Fluminense e Paulista.

Somado à mão de obra escrava, o trabalho acumulado por mais de um século de práticas predatórias deixou rugosidades (Santos, 1996) difíceis de serem superadas como a exaustão e erosão dos solos, levando à contínua ocupação dos fundos territoriais ${ }^{7}$ (Moraes, 2000). Ambas as heranças (trabalho escravo e degradação dos solos), segundo Cano (1998), promoveram custos crescentes e margens decrescentes de lucros, diminuindo a acumulação. $\bigcirc$ esgotamento das melhores terras para a cafeicultura ${ }^{8}$ e a procura por novas áreas cada vez mais distantes dos portos aumentaram os custos de transporte e o preço das terras. Com relação ao sistema servil, o preço dos escravos se elevou acentuadamente com o fim do Tráfico Negreiro, em 1850.

Mesmo a construção das ferrovias, a partir de 1852, com a inauguração da Estrada de Ferro Dom Pedro II, não foi suficiente para recuperar uma formação socioespacial decadente: sistemas técnicos agrícolas ineficientes, quando comparados às novas regiões produtivas do Oeste Paulista; solos exaustos; perpetuação da escravidão, com os escravos constituindo a principal riqueza dos Barões do café; e produtores endividados.

Diferentemente do Oeste Paulista, as ferrovias fluminenses não incorporaram novos fundos territoriais à produção cafeeira. Elas se expandiram sobre áreas de cafeicultura já consolidadas, portanto, não promoveram um aumento da "acumulação por espoliação" (Harvey, 2004), isto é, uma espécie de acumulação primeira de capital resultante, entre outros fatores, da incorporação de novas terras ao processo de acumulação dominante.

6 Para mais detalhes sobre esta questão, ver Cano (1998).

7 Segundo Moraes (2000), os fundos territoriais configuram-se como áreas ainda não ocupadas e "valorizadas" pelo modo de produção dominante.

8 O cafeeiro é uma planta muito sensível às condições climáticas e topográficas, e precisa ser cultivado em áreas de temperatura amena, com regime pluviométrico bem delimitado e altitude acima de 500 metros. 
Menos de 30 anos depois de sua inauguração, as ferrovias fluminenses foram encampadas pelo Estado devido às suas operações deficitárias.

\section{Mecanização da cafeicultura e o meio técnico}

A partir das décadas de 1870-80, as plantações de café deslocaram-se do Vale do Paraíba para o Planalto Ocidental Paulista. A grande disponibilidade de fundos territoriais, associada à difusão das ferrovias e do telégrafo e à racionalização da produção, com a difusão de novas técnicas produtivas, promoveram de maneira concomitante o aumento da área plantada e da produtividade. ${ }^{9}$

As novas áreas apresentavam características fisiográficas favoráveis - como solos férteis (terra roxa), relevo menos ondulado, quando comparado com as regiões anteriores, temperaturas amenas, e chuvas bem distribuídas - e poucas rugosidades, com o predomínio da cobertura vegetal original e a presença de posseiros e indígenas. ${ }^{10}$

Ao meio geográfico, praticamente natural, se sobrepõe a partir de então, um espaço mecanizado, com "as lógicas e os tempos humanos impondo-se à natureza com a emergência de sucessivos meios técnicos, todos incompletamente realizados, todos incompletamente difundidos" (Silveira, 2007). ${ }^{.1}$

Como assevera Santos (1996), as inovações técnicas não surgem isoladamente, mas em famílias, articulando-se de maneira sistêmica. Dessa forma, o desenvolvimento e difusão de novos sistemas técnicos vinculados à produção cafeeira (secadores, classificadores, lavadores e limpadores movidos a vapor), exigiram melhorias nos tratos culturais (curvas de nível, espaçamento e adubação), alterações na arquitetura das fazendas (construção de terreiros de alvenaria e casa de máquinas) e se associaram aos novos sistemas técnicos que funcionavam como prolongamentos (próteses) do território, como energia elétrica, telégrafo, ferrovias e portos. Todo o território circunscrito pela produção cafeeira se mecaniza, como afirma Monbeig $(1984$, p. 88), foi o triunfo do "metal e do vapor" sobre a "madeira e a água".

Em meio à paisagem monótona do café surge a máquina, representada, sobretudo, pela ferrovia. Tratava-se de novas verticalidades (Santos, 1996), isto é, eventos externos que se materializam no território, possibilitando naquela situação, novas formas de circulação e reprodução para o capital produtivo e financeiro internacional.

A construção da rede ferroviária paulista, associada aos novos procedimentos de

9 As novas lavouras do Oeste Paulista eram no mínimo cinco vezes mais produtivas do que as do Vale do Paraíba, mas, assim como as últimas, também eram itinerantes, ampliando constantemente a "frente pioneira" (Monbeig, 1984).

10 Monbeig (1984, p. 129-137) descreve os posseiros e os grupos indígenas que habitavam o interior paulista naquele momento, assim como os conflitos do embate com os colonizadores.

11 Segundo Silveira (2007), como a maioria dos sistemas técnicos eram inovações derivadas de países centrais da economia-mundo (como a máquina a vapor, o trem, o telégrafo etc.), sua implantação e difusão no território brasileiro ocorriam de forma "incompleta", isto é, eram utilizados seletivamente para escoar determinados produtos de exportação, sem alcançar a sociedade como um todo. 
beneficiamento do café, permitiram a expansão das plantações, que, segundo Monbeig (1984), se difundiam em várias frentes de forma difusa, acompanhando as faixas de terra roxa, pelo interior paulista e norte paranaense. As ferrovias seguiam de perto a expansão das fazendas, resultando em um traçado sinuoso e em um uso restrito, o que as tornariam décadas depois, em verdadeiros exemplos de rugosidades, ao se configurar como materialidades que criadas para atender a um projeto hegemônico em determinado momento, encarece, dificulta e até mesmo impossibilita outros usos possíveis em momento futuro.

No final do século XIX e início do século XX, a logística de escoamento começava na fazenda, onde os novos secadores mecânicos e classificadores a vapor, fabricados pelas empresas Lidgerwood e Taunay $\mathcal{E}$ Silva Telles, aumentavam a qualidade e diminuíam a perecibilidade do café, permitindo o seu armazenamento por vários anos (Argollo, 2004). As ferrovias acompanhavam a expansão da "frente pioneira", conectando as áreas produtoras ao porto de Santos. Este último, com a expansão da cafeicultura para o Oeste Paulista sofreu uma série de modificações para se adaptar ao aumento do volume de café exportado e ao recebimento dos primeiros navios a vapor. Os sistemas de movimento ${ }^{12}$ criados para o café facilitaram o comércio de longa distância, favorecendo as relações comerciais entre o Brasil e os centros consumidores da Europa e EUA.

A mecanização da produção e do território e a proliferação das relações de assalariamento $^{13}$ promoveram o aprofundamento da divisão social e territorial do trabalho. A expansão cafeeira, conjugada com a implantação das ferrovias e a chegada dos imigrantes, fez surgir uma verdadeira rede urbana no interior paulista (Pacheco, 1988). Diferentemente do Vale do Paraíba, o deslocamento da "frente pioneira" paulista não deixou para trás áreas desoladas, ele fez nascer uma "família de cidades" ${ }^{14}$ funcional à produção cafeeira. Além das atividades vinculadas ao café (beneficiamento, casas comissárias, bancos locais, armazéns gerais, indústrias de máquinas e sacarias e serviços de reparo e manutenção das estradas de ferro), as cidades passaram a concentrar também comércios e serviços diversos e pequenas indústrias têxteis e de alimentos. ${ }^{15}$

Somente na última década do século XIX foram fundados 41 novos municípios no interior do estado de São Paulo (Pacheco, 1988). As cidades localizadas nos pontos

12 Contel (2001, p. 357) define os sistemas de movimento como "o conjunto indissociável de sistemas de engenharia (fixos) e de sistemas de fluxos (materiais e imateriais) que respondem pela solidariedade geográfica entre os lugares".

13 Sobre a passagem do regime escravocrata para o trabalho assalariado e a emergência do capitalismo brasileiro, ver Mello (1998).

14 Para Cataia (2005, p. 3302), baseado em Santos (1965), a "família de cidades" diz respeito a um conjunto de cidades que nascem ou são refuncionalizadas segundo as demandas da dinâmica econômica hegemônica em um dado período.

15 Sobre a formação da rede urbana e a diversificação das funções das cidades resultantes da expansão cafeeira paulista, ver Geiger (1963), Pacheco (1988) e Cano (1998). 
estratégicos da malha ferroviária paulista (que adentrava os estados de Minas Gerais e Paraná) passaram a deter o controle sobre o espaço regional, confundindo-se, segundo Monbeig (1984, p. 338), "a geografia das cidades com a das comunicações". Junto à rede nasceu uma hierarquia, cujo comando era exercido pela cidade de São Paulo. A capital paulista tornou-se o nó da rede que interligava as regiões produtoras ao porto de Santos, concentrando atividades comerciais, serviços, indústrias e bancos, além de servir de residência para os produtores mais capitalizados.

Assim como no Vale do Paraíba, a cafeicultura do Oeste Paulista também era praticada em grandes propriedades monocultoras. Apesar dessa semelhança, todo o restante era diferente. A maior racionalidade produtiva, o "assalariamento" da mão de obra (colonato) e a difusão dos sistemas de transporte e comunicação transformaram as antigas fazendas "autárquicas" encontradas no Vale do Paraíba em "grandes empresas rurais" (Argollo, 2004).

A adoção de novos sistemas técnicos agrícolas acabou com a autossuficiência das antigas fazendas, inserindo-as numa divisão territorial do trabalho que transcendia as suas próprias "porteiras". A montante era cada vez mais recorrente o fornecimento: de máquinas de preparo e beneficiamento do café (indústrias nacionais e estrangeiras); de assistência técnica, oferecida pelos recém-criados institutos estatais de pesquisa; de crédito de custeio e investimento pelos comissários e bancos locais; além da renovação constante dos colonos. A jusante destacava-se a emergência da pequena indústria local de torrefação e moagem e a atuação dos comissários, corretores, exportadores e armazenadores de café.

Assim como na cafeicultura fluminense, os comissários tiveram um papel importante no início da comercialização e financiamento da cafeicultura do Oeste Paulista. Os comissários, além de formarem as ligas e negociar o café diretamente com as casas exportadoras estrangeiras no porto de Santos, eram também os principais responsáveis por fornecer o crédito de custeio e de investimento aos produtores. Como bem demonstra Contel (2011), até o final do século XIX, não havia no território brasileiro um sistema bancário bem desenvolvido. $\bigcirc$ crédito era obtido pessoalmente pelo comissário junto às casas bancárias e repassado aos produtores, sem nenhum tipo de garantia.

Contudo, com a necessidade crescente de crédito para a formação e o custeio das lavouras, criou-se uma demanda por financiamento impossível de ser atendida pelas casas comissárias. Aos poucos, os comissários, foram sendo substituídos pelas casas exportadoras nacionais e estrangeiras, que, com as ferrovias, o telégrafo, o telefone e o correio, passaram a comprar o café diretamente nas regiões produtoras (Perosa, 1980). ${ }^{16}$

16 S. Silva (1986) demonstra como o capital agrícola cafeeiro se instalou nas cidades (São Paulo, Santos e principais centros urbanos do interior) e se diversificou em capital mercantil, bancário e industrial. Os grandes fazendeiros também eram, em muitos casos, donos de indústrias, bancos e principais casas comerciais, muitas vezes em parceria com o capital estrangeiro. 
Desde cedo, os produtores nacionais estavam subordinados à lógica das commodities (Frederico, 2013), isto é, não tinham nenhum controle sobre a classificação e os preços do café estipulados pela bolsa de valores de Nova lorque. As exportações brasileiras eram monopolizadas por um grupo seleto de grandes empresas estrangeiras, que além de controlar o comércio internacional, também tinham armazéns que lhes permitiam estocar o café de um ano para outro, comprando o café nos anos de alta produção e preços baixos e vendendo-o nos anos de baixa produção e preços relativamente mais elevados (Holloway, 1978). Como afirma Monbeig (1984), "o movimento pioneiro paulista era cada vez mais um negócio mundial”, com as firmas estrangeiras adquirindo também terras e plantações.

A vulnerabilidade da cafeicultura brasileira não se restringia à regulação externa da produção, mas também aos constantes problemas de superacumulação (Cano, 1998). Este último era agravado pela falta de alternativa produtiva ao café (Furtado, 1976) e por se tratar de uma cultura perene, com um longo ciclo produtivo. Nos momentos de alta dos preços, os produtores capitalizados se sentiam estimulados a aumentar a área plantada. No entanto, as novas plantas demoravam cerca de quatro anos para começar a produzir. Quando as novas plantas alcançavam sua máxima capacidade produtiva, o aumento da oferta resultava em uma acentuada redução dos preços, que permaneciam deprimidos nos anos seguintes, até que uma intempérie climática (geada) ou intervenção política alterasse a situação (Delfim Netto, 1981).

Nas primeiras décadas do século XX, como o café representava mais de $50 \%$ do valor das exportações brasileiras, o Estado adotou uma série de políticas de intervenção na cafeicultura. Segundo Saes (1995), até 1929, a "política regulatória" era circunstancial, atuando somente nos anos de superprodução e consequente baixa acentuada dos preços. As políticas consistiam na compra do excesso de produção e na formação de estoques. ${ }^{17}$ Ao adquirir o excesso de produção e reter os estoques, o Estado mantinha valorizados os preços do café, estimulando o aumento da produção.

A crise internacional de 1929, ao deprimir a demanda mundial e aumentar o excedente de café, apenas antecipou os problemas iminentes da cafeicultura brasileira decorrentes da superacumulação. Como consequência, nas décadas de 1930 e 1940, - Estado brasileiro adotou uma política cujo objetivo era equilibrar a relação entre oferta e consumo. Os principais instrumentos dessa política foram: a destruição dos cafés de qualidade inferior; a criação de quotas de exportação; e a taxação e posterior proibição de novos plantios (Bacha, 1988). Com isso, houve uma redução significativa da área plantada ${ }^{18}$ e da importância do café na economia nacional, que cede lugar gradativamente a uma economia urbano-industrial, diminuindo o poder político dos

17 A primeira intervenção do Estado no mercado cafeeiro ocorreu com o Convênio de Taubaté, em 1906. Depois, foram feitas intervenções nos anos de 1918 e 1921 e, de forma permanente, entre 1924 e 1929.

18 Aárea plantada de café passou de cerca de quatro milhões de hectares no triênio 1931-33, para aproximadamente 2,6 milhões de hectares no triênio 1949-51 (Bacha, 1988). 
agentes atrelados à cafeicultura (Furtado, 1976; Cano, 1998).

O estado de São Paulo, apesar de se manter como o principal produtor de café até a década de 1950, foi o que sofreu a maior redução da área plantada, diminuindo a sua participação percentual no total do país de $57 \%$, no triênio $1931 / 33$, para $38 \%$ no triênio 1958/60 (Bacha, 1988). Além da crise e das políticas de desestímulo, a cafeicultura paulista também sofreu a concorrência de outras culturas como o algodão e a cana-deaçúcar.

Como decorrência da derrocada paulista, a cafeicultura se expandiu rapidamente no norte do estado do Paraná. Área de expansão da frente pioneira paulista desde a década de 1920, a região tornou-se, na década de 1960, a maior produtora nacional (Bacha, 1988). Contudo, o apogeu da cafeicultura paranaense foi curto, devido à inadequação climática de grandes áreas, com fortes geadas, como a do ano de 1975, que destruiu a totalidade dos cafeeiros, e a crescente concorrência com a produção de grãos, em particular, de soja, a partir da década de 1970.

Com relação a Minas Gerais houve uma contração da cafeicultura na região da Zona da Mata (cuja produção foi substituída em parte pela produção leiteira) e uma expansão na região do sul de Minas, que em 1939 já era a principal região produtora do estado (Bacha, 1988). Porém, esta última somente se tornou a principal região produtora brasileira a partir da década de 1970, com as políticas de erradicação e modernização da cafeicultura, analisadas a seguir.

A crise da década de 1930, também alterou em grande parte a estrutura fundiária da cafeicultura brasileira, fazendo surgir os "sítios de café" (Argollo, 2004). Desde o final do século XIX, as pequenas propriedades de café já conviviam em meio às "grandes empresas rurais". Mas, a partir daquela década, as pequenas plantações tornaram-se predominantes, sobretudo, nas áreas de expansão do estado de São Paulo, do norte do Paraná e do sul de Minas Gerais.

As "franjas pioneiras" (Monbeig, 1984) 19 passaram a intercalar grandes fazendas com pequenos sítios, que tinham um traço em comum, o cultivo de várias culturas. Além do café passaram a cultivar também algodão, cana-de-açúcar, produtos alimentícios e pastagens. Portanto, a crise internacional decretou o fim do império da grande fazenda monocultora de café, que durante décadas foi o principal motor do desenvolvimento capitalista brasileiro e da tecnificação de seu território.

Como demonstrado por diversos autores como Furtado (1976), Cano (1998) e S. Silva (1986), a cafeicultura paulista foi a principal responsável pela modernização de parte da economia e do território brasileiro, reunindo as densidades técnicas necessárias

19 Para Monbeig (1984), as "franjas pioneiras" caracterizavam-se como as áreas recém-ocupadas pelos colonizadores, a partir da implantação de uma atividade produtiva considerada moderna. Na situação em análise, o autor enfatiza a expansão cafeeira, especialmente durante a década de 1930, em direção ao Oeste Paulista e ao norte paranaense, em paralelo à criação de cidades e à implantação de infraestruturas de transporte e comunicação. 
para a formação da região Concentrada (Santos; Ribeiro, 1979). Ela estimulou a industrialização (ainda que "restringida"), a urbanização, o desenvolvimento do sistema financeiro e de serviços, a imigração (mão de obra assalariada), a criação de redes de transporte e comunicação (momento preliminar à integração territorial brasileira), a formação de uma rede urbana interior no estado de São Paulo e a conformação da capital paulista como uma emergente metrópole industrial.

Com o crescimento da economia urbano-industrial e de outras atividades agrícolas como a produção de grãos, a cafeicultura perdeu gradativamente o seu protagonismo. Apesar disso, até a década de 1970, o café ainda se manteve como o principal produto de exportação brasileiro, sendo o grande responsável pela geração de divisas para a industrialização naquele período. Devido à sua importância, ainda que declinante, a cafeicultura brasileira foi fortemente reestruturada com a internalização do pacote tecnológico oriundo do paradigma da Revolução Verde, como abordado a seguir.

\section{Cientifização da cafeicultura e meio técnico-científico}

A partir das décadas de 1960-70, a agricultura brasileira sofreu profundas transformações, com a difusão de novos sistemas técnicos e a presença significativa do Estado, como principal articulador e financiador de sua modernização (Silva, J., 1982; Mazzali, 2000). As alterações estavam inseridas dentro de um contexto mais amplo de tecnificação e cientifização do território brasileiro (Santos, 1994).

A nova situação geográfica (Silveira, 1999), se caracterizava pela difusão de uma psicoesfera (Santos, 1996), pautada na ideologia do consumo, do crescimento econômico e do desenvolvimentismo; e de uma tecnoesfera, por meio da construção de macrossistemas técnicos (rodovias, portos, sistemas de comunicação, usinas hidrelétricas, infraestruturas urbanas, indústrias, modernização agrícola), que possibilitou e exigiu uma maior fluidez e gradativa integração do território brasileiro (Santos; Silveira, 2001).

O café, ainda na década de 1970, era o principal produto brasileiro de exportação, responsável direto pela geração de divisas necessárias à industrialização (via substituição de importações), aos investimentos diretos do Estado para desenvolver a indústria de base e implantar os sistemas de engenharia. A dependência com relação à economia cafeeira levou o Estado a patrocinar uma política de modernização e racionalização da cafeicultura, com o intuito de aumentar a produtividade, a despeito das sucessivas superproduções, recorrentes desde o início do século XX (Bacha, 1988; Saes, 1995).

Segundo L. Silva (1994, p. 17), as intervenções estatais na cafeicultura, até a década de 1950, eram muito mais "políticas públicas para a manutenção da renda" sobretudo dos grandes produtores, do que um planejamento sistemático de modernização da produção em bases científicas. Essa relação se altera com a criação do Instituto Brasileiro do Café (IBC), em 1952, e dos AIC, entre 1962 e 1989.

$\mathrm{O} I \mathrm{IBC}$ foi criado com o objetivo de regular o mercado e a política cafeeira e adequar a cafeicultura brasileira ao novo modelo tecnológico-produtivista (Silva, L., 1994). 
Com a crise de superacumulação de café da década de 1960 (Delfim Netto, 1981), o órgão estatal assumiu efetivamente as funções de planejar e coordenar os diferentes segmentos do circuito produtivo do café: produção propriamente dita, transformação industrial, distribuição e consumo.

Entre as ações do IBC, destaca-se a criação do Grupo Executivo de Racionalização da Cafeicultura (Gerca), que, na década de 1960, promoveu a erradicação de quase metade da população cafeeira brasileira, sobretudo, das lavouras pouco produtivas ou localizadas em regiões consideradas inadequadas. ${ }^{20} \mathrm{Na}$ década seguinte, o Gerca criou o Plano de Renovação e Revigoramento de Cafezais (PRRC) que reestruturou os sistemas técnicos agrícolas da cafeicultura brasileira, por meio da concessão de crédito subsidiado, da inovação tecnológica e da assistência técnica (Bacha, 1988; Silva, L., 1994).

Os cafeeiros tradicionais (Bourbon e Comum), predominantes até então, foram substituídos, sobretudo, pelas variedades Mundo $\mathrm{Novo}^{21}$ e Catuaí de alto rendimento e sensíveis ao uso dos insumos químicos e mecânicos. Os novos cultivares foram desenvolvidos pelo Instituto Agronômico de Campinas (IAC), com o financiamento de grandes empresas nacionais e multinacionais (Fundação Rockfeller, Shell Mex, Standard Oil, Anderson Clayton, Moinho Santista, Serrana, Manah) (Frederico, 2013).

Os financiamentos coincidiram, no caso das multinacionais, com a internalização dessas empresas no território brasileiro, dentro de um contexto de adoção do paradigma da Revolução Verde (Porto-Gonçalves, 2006) e formação dos complexos agroindustriais (Müller, 1989; Kageyama et al., 1990).

A concessão de crédito pelo Gerca/IBC estava condicionada ao plantio das novas variedades e ao uso dos insumos químicos e mecânicos, distribuídos principalmente pelas empresas multinacionais, sob orientação dos institutos de pesquisa estatais. ${ }^{22}$

Com a adoção dos novos cultivares, o consumo de adubo químico e agrotóxicos aumentou em todos os estados produtores. No início da década de 1960, praticamente nenhuma região produtora utilizava adubação química ou agrotóxicos; em 1980, a adubação era realizada em mais de $90 \%$ da área plantada dos estados de Minas Gerais e São Paulo e os agrotóxicos eram empregados em pelo menos $60 \%$ da área plantada dos principais estados produtores, alcançando $84 \%$ no estado de Minas Gerais. ${ }^{23}$

Com o plantio dos novos cultivares, a introdução de novas técnicas de manejo e o

20 Entre 1961 e 1968, reduziu-se o número de pés de café brasileiro de 4,3 para 2,3 milhões (Bacha, 1988).

21 A variedade Mundo Novo foi criada pelo IAC em 1943, mas a difusão de seu uso ocorre principalmente a partir das políticas de racionalização da cafeicultura na década de 1970.

22 Até o início de 1960, no estado de Minas Gerais, 94\% da população cafeeira era composta pelas variedades Comum e Bourbon; em meados da década de 1980, essas variedades representavam menos de $10 \%$ do total, enquanto as variedades de alto rendimento (Mundo Novo e Catuai) representavam cerca de $90 \%$ dos cafeeiros (Bacha, 1988).

23 Os dados sobre produtividade, adubação e uso de agrotóxicos usados neste item foram obtidos em Bacha (1988). 
uso dos insumos químicos e mecânicos, a produtividade média da cafeicultura brasileira passou de 21,7 para 35 sacas de café em coco/hectare, entre 1969 e 1985. O estado de Minas Gerais foi o que apresentou o maior crescimento da produtividade passando de 17,3 para cerca de 40 sacas de café em coco/hectare, no mesmo período (Bacha, 1988).

Além da revolução tecnológica realizada na esfera produtiva, o IBC também atuava nos demais segmentos da cafeicultura. Ele estimulou o crescimento do consumo interno de café, como uma alternativa às crises de superprodução, tornando o mercado brasileiro o segundo maior do mundo (atrás dos EUA), assim como controlava a abertura de novas indústrias de torrefação e moagem e de café solúvel.

O órgão estatal estipulava as quotas e os preços da matéria-prima obtida pelas indústrias e tabelava o preço do café torrado e moído vendido nas prateleiras dos supermercados. Com relação à indústria de solúvel, ela foi criada na década de 1960 , com o intuito de utilizar os grãos quebrados, que não conseguiam ser comercializados, e como forma de agregar valor às exportações brasileiras de café.

Ainda no contexto de forte atuação estatal e de momento de crítica à lógica das "vantagens comparativas" (Reinert, 2007) foram criados os Acordos Internacionais do Café e o seu órgão gestor, a Organização Internacional do Café (OIC), no início da década de 1960. O objetivo era tentar equilibrar a relação entre a oferta e a demanda de café no mercado internacional, estipulando quotas de exportação para os países produtores e regulando os preços (Daviron; Ponte, 2007). O sucesso dos AIC derivou da adesão dos EUA (principal consumidor e importador mundial), fortemente influenciada pelo contexto geopolítico da Guerra Fria, e da posição aceita pelo Estado brasileiro (principal produtor e exportador mundial) de formar estoques de café e exportar menos do que o estipulado pela sua quota (Talbot, 2004).

Devido à dependência das divisas geradas pelo café, o Estado brasileiro permitiu que a sua participação no total das exportações fosse reduzida gradativamente em troca da valorização dos preços e da garantia de sobrevivência dos AIC. Até porque, com a industrialização e diversificação de sua pauta exportadora, a participação do café na receita das exportações brasileiras reduziu-se drasticamente, diminuindo o seu peso estratégico, ao passar de 56\%, em 1960, para apenas 5\%, no início da década de 1990 (Saes, 1995).

A revolução dos transportes (Natal, 1991), que teve lugar no Brasil nas décadas de 1950 e 1960, transformou a logística de escoamento do café. As ferrovias, que no período anterior viabilizaram a expansão das frentes cafeeiras, foram substituídas pelo modal rodoviário. As estradas e o caminhão deixaram de ser complementares às estradas de ferro para se tornarem protagonistas no transporte do café.

Apesar da mudança no modal de transporte, o porto de Santos se manteve como o principal exportador de café. $O$ traçado das rodovias, assim como as ferrovias antes delas, reafirmou a centralidade de Santos, principalmente com relação às tradicionais regiões produtoras de São Paulo e do sul de Minas. Nas áreas de expansão, como no cerrado mineiro, as rodovias também substituíram as ferrovias como as principais artérias de penetração. 
Seguida à revolução dos transportes, a revolução das telecomunicações (Dias, 1995), na década de 1970, também alterou a divisão territorial do trabalho, reforçando a centralidade da metrópole de São Paulo. No caso do café, a Bolsa Oficial do Café de Santos cedeu lugar à Bolsa de Mercadorias e Futuros (BMEF), localizada na cidade de São Paulo, como a principal reguladora do mercado cafeeiro brasileiro (Frederico, 2013).

A Bolsa Oficial do Café havia sido criada em 1914, com o objetivo de regular o comércio de café, pela fixação e publicização das cotações, da arrecadação dos impostos de exportação, da garantia da realização dos negócios e da veracidade das informações sobre a origem e a qualidade do café. Ela encerrou as suas atividades em fins da década de 1970, quando a BMEF se tornou a responsável por fechar os negócios e anunciar as cotações dos preços do café brasileiro no mercado "disponível" e futuro.

As relações de produção predominantes no campo também se alteraram substancialmente com as transformações de ordem técnica e política ocorridas naquele período. O regime de colonato foi substituído pelo trabalhador assalariado permanente e, sobretudo, temporário. Segundo Bacha (1988), a erradicação dos cafezais na década de 1960, as novas leis criadas pelo Estatuto do Trabalhador Rural ${ }^{24}$ (Brasil, 1963) e as mudanças técnicas foram os principais fatores responsáveis pela alteração das relações de produção na cafeicultura.

Com o fim do trabalho escravo, no final do século XIX, foram adotados três principais tipos de relação de produção, que conviviam com a mão de obra familiar: o "colonato", ${ }^{25}$ predominante no estado de São Paulo e sul de Minas, a "meação" 26 e a "turma", ${ }^{27}$ recorrentes na Zona da Mata Mineira e no Espírito Santo. Na segunda metade da década de 1960, essas antigas formas de relação foram substituídas pelo trabalhador assalariado permanente, residente ou não nas propriedades agrícolas, e principalmente pelos trabalhadores temporários contratados nos momentos de maior demanda por mão de obra, como nos meses de colheita.

Segundo Bacha (1988, p. 179), o Estatuto do Trabalhador Rural aumentou os custos de produção, ao reconhecer, mesmo que parcialmente, os direitos trabalhistas dos trabalhadores rurais, e o conjunto de inovações técnicas "ampliou a descontinuidade entre as etapas produtivas do café", diminuindo a importância da presença permanente

24 Estatuto do Trabalhador Rural (Brasil, 1963) equiparava os direitos trabalhistas dos trabalhadores rurais aos dos trabalhadores urbanos, obrigando pagamento de salário mínimo, descanso remunerado, férias e indenização em caso de dispensa.

25 De modo geral, no regime de colonato, o trabalhador recebia uma quantia fixa pelo manejo de determinada número de cafeeiros, uma remuneração por dia de trabalho de tratos culturais (poda e adubação), e uma remuneração por número de balaios de café colhidos, na época da colheita. Os colonos viviam nas fazendas e podiam usar parte das terras para o cultivo de gêneros alimentícios, e sobretudo para sua subsistência (Delfim Netto, 1981).

26 A meação consiste num sistema de parceria entre o proprietário da terra e os trabalhadores, que recebem o pagamento em café pelo manejo de determinado número de cafeeiros, e não há assalariamento.

27 A turma era um tipo de colonato, no qual os trabalhadores residiam nas fazendas e recebiam diárias; na época, da colheita recebiam também um diferencial pelo número de balaios colhidos (Valverde, 1970; Bacha, 1988). 
de um grande número de trabalhadores nas fazendas.

Com relação à dinâmica regional, entre as décadas de 1960 e 1980, um dos eventos mais significativos, com a introdução dos novos sistemas técnicos agrícolas, foi o aprofundamento da especialização produtiva, promovendo a reestruturação de antigas regiões produtoras e o deslocamento para novas áreas.

Na década de 1960, os estados do Paraná e de São Paulo eram os dois principais produtores de café, com cerca de $50 \%$ e $30 \%$ da produção brasileira, respectivamente (Bacha, 1988). No final dos anos de 1980, o estado de Minas Gerais havia se tornado o principal estado produtor, seguido por São Paulo e Espírito Santo.

No estado de São Paulo, a maior densidade técnica e de capital e a facilidade de circulação promoveram novos usos agrícolas de seu território. $\bigcirc$ café, que durante o final do século XIX e início do século XX, foi o principal indutor da tecnificação do território paulista, cedeu espaço para a cana-de-açúcar e a laranja. As duas últimas, além de serem mais lucrativas que o café, apresentavam menores custos de produção e menores incertezas com relação às oscilações das cotações internacionais. A canade-açúcar também foi favorecida pelo Proálcool criado como uma resposta à crise energética da década de $1970 .^{28}$

No caso do Paraná, as novas variedades de café de alto rendimento eram mais sensíveis às intempéries climáticas. No ano de 1975, fortes geadas praticamente dizimaram a cafeicultura paranaense, que também sofria com a concorrência da expansão dos grãos, sobretudo, da produção de soja.

Com o declínio das cafeiculturas paranaense e paulista, Minas Gerais se tornou o principal estado produtor. A partir da década de 1970, o café se expandiu principalmente no sul de Minas e no cerrado mineiro, que se tornaram as maiores regiões produtoras brasileiras da variedade Arábica (Bacha, 1988).

A primeira é uma antiga região produtora de café, cuja atividade se implantou na segunda metade do século XIX, como decorrência da expansão da cafeicultura paulista. No momento da reestruturação tecnológica-produtivista da década de 1970, o espaço sul mineiro apresentava rugosidades, que neste caso facilitaram a modernização da cafeicultura. Entre as heranças físico-territoriais e sociopolíticas destacam-se: disponibilidade de terras ociosas e uma estrutura fundiária desconcentrada, decorrente principalmente das divisões por herança e do desmembramento de algumas fazendas cafeeiras com a crise de 1929; grande disponibilidade de mão de obra; preço da terra inferior ao dos estados de São Paulo e Paraná; condições edafoclimáticas propícias à cafeicultura e topografia ondulada que limitava a expansão de culturas concorrentes como a soja e a cana-de-açúcar. ${ }^{29}$

28 Entre 1972 e 1993, o café, a pecuária e o algodão perderam cerca de 2,1 milhões de hectares no estado de São Paulo, área equivalente praticamente à expansão da cana-de-açúcar e da laranja (Bacha, 1996).

29 Os aspectos aqui mencionados são analisados mais detalhadamente por Bacha (1988) e Cano (2002). 
Como consequência, o sul de Minas não tinha alternativas econômicas mais rentáveis que o café, principalmente, com os altos preços da década de 1970 e o mercado deixado pelo declínio da cafeicultura paulista e paranaense (Cano, 2002). Somado às heranças territoriais, as políticas estatais de estímulo à modernização e expansão da cafeicultura (PRRC) tornaram a região a maior produtora de café do território brasileiro.

Assim como o sul de Minas, o cerrado mineiro também recebeu aportes financeiros subsidiados para a expansão da cafeicultura pelo PRRC. Mas, ao contrário do relevo ondulado e dos solos férteis da primeira, o cerrado tem uma topografia plana e solos ácidos, que, se por um lado facilitaram a mecanização, por outro, exigiram o uso mais intensivo de adubos químicos e fertilizantes. Naquela região, a cafeicultura se difundiu em médias e grandes propriedades, em substituição à vegetação original e a pequena produção de subsistência.

Contudo, o padrão "tecnológico-produtivista" da cafeicultura brasileira se esgotou no final da década de 1980 (Silva, L., 1994). O ideário do desenvolvimentismo, dominante até então, cedeu lugar aos ideários da competitividade e da sustentabilidade ambiental (Gorz, 2004; Castillo, 2008), com a difusão da ideologia e das políticas neoliberais na década de 1990.

A cafeicultura, fortemente regulada pelo Estado, paulatinamente foi substituída, ao menos em algumas regiões, por uma cafeicultura científica globalizada, pautada: na eficiência produtiva, com redução de custos, aumento da produtividade e racionalização do uso de agrotóxicos; na diferenciação qualitativa (cafés especiais); no uso do marketing (atrelado principalmente ao discurso da "sustentabilidade"); e na inserção competitiva nos mercados internacionais (Frederico, 2014).

Durante a vigência das políticas estatais e internacionais de regulação do mercado cafeeiro, entre as décadas de 1960 e 1980, houve uma valorização dos preços internacionais (maiores médias históricas) e o aumento percentual da participação dos produtores no valor final do produto (Daviron; Ponte, 2007). Outra questão estratégica era a retenção dos estoques de café pelos Estados produtores, o que lhes conferiam maior autonomia política e poder de regulação dos preços internacionais.

Com a adoção das políticas neoliberais e a "desregulamentação" (nova regulação) da política cafeeira, a partir da década de 1990, houve uma queda dos preços internacionais do café e a diminuição acentuada do percentual recebido pelo produtor do valor final do produto, que alcançaram os menores índices históricos. Os estoques, antes regulados pelos países produtores, foram transferidos para as grandes empresas 
torrefadoras sediadas nos países importadores, aumentando o seu poder de regulação da produção.

Cafeicultura científica globalizada e o meio técnico-científico-informacional

Com a Globalização (Santos, 2000), a cafeicultura brasileira incorporou no discurso e na prática os ideários da competitividade e da sustentabilidade (Castillo, 2008). A competitividade trata-se da eficiência produtiva e da inserção proeminente da produção nos mercados internacionais. Já o ideário da sustentabilidade deriva, no caso da cafeicultura, das exigências de grande parte dos consumidores dos países centrais da adoção de formas de produção consideradas "socialmente justas" e "ambientalmente adequadas" (Souza, 2006).

Os ideários dominantes do atual período induziram mudanças no paradigma produtivo anterior. À cafeicultura herdeira dos sistemas técnicos derivados da Revolução Verde e fortemente regulada pelo Estado se sucedeu uma cafeicultura científica globalizada, caracterizada por grandes transformações de ordem política, com a difusão do ideário neoliberal, e técnica, com a adoção de tecnologias da informação no sistema produtivo.

As alterações político-normativas resultaram na diminuição da intervenção estatal, sobretudo, com o fim dos Acordos Internacionais do Café, em 1989, e a extinção do Instituto Brasileiro do Café em 1990. A partir de então, os preços do café passaram a flutuar livremente na bolsa de valores e as grandes corporações ocuparam gradativamente antigas funções delegadas ao Estado, como o fornecimento de crédito ao produtor e o controle dos estoques. A nova regulamentação neoliberal também facilitou a aquisição de empresas nacionais de torrefação e comercialização por grandes grupos internacionais, que passaram a se estruturar em verdadeiros oligopólios, na venda do café processado, e oligopsônios, na compra do grão verde ${ }^{30}$ (Talbot, 2004; Daviron; Ponte, 2007; Frederico, 2013). Os estoques de café, até então controlados pelos países produtores foram transferidos para os países consumidores e passaram a ser controlados por um pequeno grupo de grandes empresas. Com isso, os preços internacionais do café alcançaram as menores médias históricas no início da década de 1990 e durante a década de 2000, como ilustra o gráfico a seguir.

30 Em 2010, só cinco empresas controlavam cerca de 50\% do comércio mundial de café verde (Neumann, Ecom, Olam, EdEF Man e Louis Dreyfus), assim como outras cinco torrefadoras também controlavam cerca de $50 \%$ da venda mundial de café processado (Kraft/Philip Morris, Nestlé, Sara Lee, J.M. Smucker's e Elite) (Frederico, 2013). 


\section{Gráfico 1}

Variação do preço médio do café verde (1965-2011)

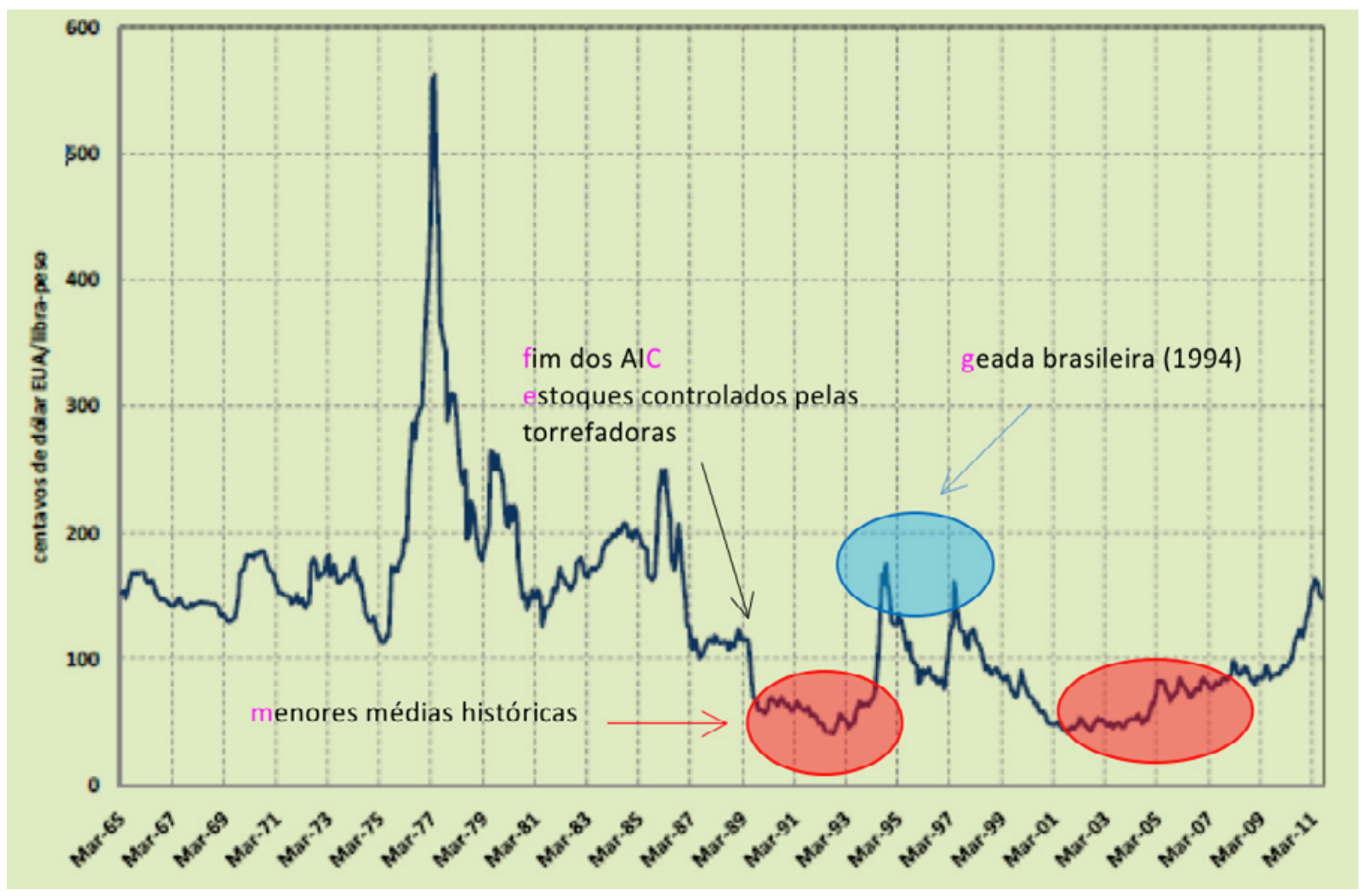

fonte: Organização Internacional do Café (2012). Deflacionado pelo índice ONU (2000 = 100).

Segundo Daviron e Ponte (2007), com a globalização, a cafeicultura mundial passou a se caracterizar por um verdadeiro "paradoxo". Se por um lado houve uma queda acentuada dos preços do café em grão e da participação dos produtores no valor final do produto servido ao consumidor, por outro lado, houve um aumento do consumo e uma agregação de valor no produto final, com a proliferação de bares-café, redes de cafeterias e de novas formas de consumo. Para os autores, enquanto os produtores ganham cada vez menos, as grandes empresas passaram a ganhar cada vez mais com a agregação de valores "simbólicos" e de "prestação de serviços" ao produto final, cujo modelo de negócio criado pela rede de cafeterias Starbucks parece ser o melhor exemplo (Frederico, 2013).

Ao analisar a divisão da renda total da "cadeia de valor mundial do café" entre as décadas de 1970 e 1990, Talbot (2004, p. 166-168) estima que durante a vigência dos AIC, os países consumidores retinham metade do valor final do café torrado/moído e solúvel vendido ao consumidor final; enquanto os países produtores, transportadores e cafeicultores se apropriavam da outra metade. Naquele período (décadas de 1970-80), os produtores se apropriavam de cerca de $20 \%$ do valor final, chegando a $30 \%$ do total no ano safra de 1975/76, após as geadas no estado do Paraná. 
Contudo, a relação se alterou drasticamente com o fim dos AIC, em 1989. A denominada "desregulamentação" do mercado cafeeiro - que foi na verdade uma nova forma de "regulação corporativa" -, fez com que o percentual da renda total do café apropriado pelos países importadores aumentasse para $75 \%$, enquanto a participação dos cafeicultores caiu para apenas 13\%, entre 1989 e 2000 (Talbot, 2004).

Além da regulação das empresas, Talbot (2004) demonstra ainda como os produtores também se tornaram reféns das especulações financeiras. Segundo dados do International Trade Center (ITC, 2012), entre 1980 e 2010, houve um acentuado descolamento entre o montante de café físico comercializado no mercado mundial e a quantidade negociada no mercado futuro. Nesse período, o mercado físico de café aumentou de 4,1 para 7,9 milhões de toneladas, enquanto a quantidade de café negociada no mercado futuro passou de 20,7 para 121,8 milhões de toneladas, cerca de 15 vezes a quantidade de café comercializada no mercado físico. ${ }^{31}$ Como ressalta Frederico (2013), a crescente negociação das commodities agrícolas como derivativos puramente financeiros resulta no aumento das oscilações dos preços do café, com forte impacto, sobretudo, entre os pequenos produtores sem acesso às informações de mercado e à possibilidade de "travar" o preço de seu café no mercado futuro. ${ }^{32}$

Às alterações de ordem político-normativa anteriormente destacadas, adicionamse também as inovações de ordem técnica, criadas com o objetivo de aumentar a produtividade e de adequar a produção às exigências dos mercados internacionais. Aos sistemas técnicos oriundos do paradigma da Revolução Verde somam-se agora as tecnologias da informação e da comunicação (TIC). A associação entre a informática e as telecomunicações, além de permitir o controle remoto da produção, redefinindo a autonomia e a hierarquia regional (Santos, 1994, 1996), também viabilizou o desenvolvimento de novos sistemas técnicos como a biotecnologia, a agricultura de precisão, o monitoramento de riscos climáticos e a criação de bancos de dados.

O melhor exemplo do uso das TIC na cafeicultura brasileira foi a fundação do Consórcio Pesquisa Café (CPC). Criado em 1996, ele reúne atualmente quase 50 instituições de pesquisa, localizadas nos principais estados e regiões produtoras, sendo administrado pela Embrapa-Café. O Consórcio substituiu o extinto IBC como o principal financiador e articulador do desenvolvimento de pesquisas ligadas à cafeicultura brasileira.

Com o uso dos recursos do Fundo de Defesa da Cafeicultura (Funcafé), as pesquisas em rede desenvolvidas pelo CPC têm resultado numa série de novos sistemas técnicos-normativos para a cafeicultura, desde o desenvolvimento de novas práticas de manejo e de variedades resistentes a pragas e doenças até o uso de imagens

31 Teoricamente, a quantidade de café comercializada no mercado futuro deveria ser duas vezes maior do que aquela negociada no mercado físico, uma vez que, para cada contrato de venda, há também um contrato de compra.

32 Para uma análise detalhada sobre esta questão, ver Frederico (2013). 
de satélite e a disseminação de estações climáticas para o zoneamento agroclimático, sem desconsiderar o uso da biotecnologia, a diversificação dos produtos derivados do café (cosméticos, sorvetes, bebidas diversas etc.) e o incentivo à criação de indicações geográficas e à produção de cafés especiais. ${ }^{33}$

Entre as principais expressões territoriais da cafeicultura científica globalizada destaca-se a ampliação da divisão do trabalho e o consequente aprofundamento da especialização produtiva regional. As regiões cafeeiras, que naturalmente se diferenciavam pelas suas características climáticas e morfológicas - que interferem diretamente na qualidade da bebida -, passaram a se distinguir ainda mais com o desenvolvimento de novos sistemas técnicos e normativos adaptados às suas particularidades produtivas e fisiográficas.

Enquanto nas tradicionais regiões cafeeiras, como o sul de Minas, os novos sistemas técnicos convivem com práticas agrícolas precedentes, acarretando numa simultaneidade de divisões territoriais do trabalho. Nas áreas de expansão da fronteira agrícola moderna, o "novo" se difunde com muito mais facilidade, como no caso do oeste da Bahia.

Assim como o cerrado mineiro, duas décadas antes, o oeste da Bahia se tornou, a partir da década de 1990, a nova área de expansão da cafeicultura científica globalizada. A disponibilidade de fundos territoriais e as poucas rugosidades permitiram a rápida difusão de uma cafeicultura intensiva em capital e tecnologia. Apesar de não se constituir como a principal atividade agrícola da região e nem mesmo ter grande participação no volume total de café produzido no Brasil, a cafeicultura do oeste da Bahia caracteriza-se como um novo paradigma produtivo para a cafeicultura brasileira e mundial: produção em grandes propriedades, presença de grandes grupos empresariais, uso da irrigação, colheita e tratos culturais totalmente mecanizados, elevada produtividade e baixos custos relativos de produção.

No oeste da Bahia, a exigência de eficiência produtiva, promovida pela presença de grandes produtores e empresas capitalizados e pela elevação do rendimento da terra, inviabiliza a criação de alternativas ao modelo agrícola de produção intensiva em grandes propriedades, podendo num futuro incerto acarretar perturbações nas demais regiões cafeeiras. $O$ uso de sistemas técnicos agrícolas extremamente eficientes do ponto de vista produtivo, destinados a realizar funções precisas, acabam por reduzir significativamente os custos médios de produção e aumentar as taxas de mais-valia, o que acaba por impor novos padrões de produtividade e competitividade às demais regiões cafeeiras do Brasil e do mundo. ${ }^{34}$

33 Para uma análise detalhada dos projetos de pesquisa e resultados das inovações financiadas pelo Consórcio Pesquisa Café nas diferentes Universidades e Institutos de Pesquisa vinculados à rede, consultar Embrapa ([s.d]) e Consórcio Pesquisa Café ([s.d]).

34 Para uma discussão detalhada sobre a influência do sistema produtivo adotado no oeste da Bahia em outras regiões brasileiras, ver Frederico (2012). 


\section{Considerações finais}

Após mais de dois séculos de consecutivas transformações técnico-políticas, a cafeicultura brasileira apresenta grande diversidade regional, derivada de diferentes formas de coexistência de sucessivas divisões territoriais do trabalho. Desde as montanhas capixabas, onde predomina uma cafeicultura de base familiar, com o uso de sistemas técnicos rudimentares, com colheita manual e baixa produtividade; até o oeste da Bahia, onde se tem uma cafeicultura totalmente mecanizada e irrigada, com alta produtividade e baixos custos de produção, sem desconsiderar as inúmeras situações intermediárias como o sul de Minas, a mogiana paulista e o cerrado mineiro.

Devido à abrangência do tema e ao tamanho limitado deste artigo, elencamos apenas os eventos mais importantes que auxiliam a definir cada período. $O$ intuito não foi estabelecer datas precisas para o início e o fim de cada um deles, mas enfatizar suas principais transformações de ordem técnicae política, respectivamente: as transformações técnicas internas e externas às unidades produtivas (maquinários, cultivares, insumos, sistema de transporte etc.) e as mudanças nas formas de regulação da produção, com ênfase na atuação do Estado e das grandes corporações internacionais. Importante ressaltar que algumas características de um período anterior continuam presentes no período subsequente, manifestando-se diferentemente entre as regiões produtoras. Daí a ideia de sucessão e coexistência de diferentes divisões do trabalho numa mesma região.

De maneira geral, os quatro grandes períodos da cafeicultura brasileira identificados neste artigo coincidem propositalmente com a proposta de periodização de Santos e Silveira (2001) de sucessão dos meios geográficos no território brasileiro. Desde o período pré-mecânico (meio natural), com a prática de uma cafeicultura itinerante e predatória dos recursos naturais, até o período técnico-científico-informacional (Santos, 1994, 1996), com a gradual implantação, a partir da última década do século XX, de uma cafeicultura científica globalizada, com o uso de sistemas técnico-informacionais e regulada por grandes corporações mundiais. Todavia, não se pode desconsiderar também os dois momentos intermediários, com a difusão do mundo maquínico (meio técnico), a partir da construção de ferrovias e máquinas de beneficiamento de café, entre a segunda metade do século XIX e o início do XX, e, sucessivamente, a renovação da cafeicultura brasileira e mundial com a internalização do paradigma da Revolução Verde e a forte regulação estatal por meio dos AIC e do IBC, entre a década de 1950 e o fim dos anos de 1980.

Concomitante às alterações de ordem técnica e política, a cafeicultura brasileira também conheceu um importante deslocamento territorial ao longo desses quatro períodos. A cada momento, as regiões recém-incorporadas pela expansão da produção cafeeira foram as principais representantes do novo paradigma produtivo, enquanto as áreas anteriormente ocupadas eram abandonadas pela cafeicultura ou conheciam uma sobreposição de diferentes temporalidades e divisões do trabalho. Como afirma Santos (1996), a difusão do "novo", isto é, dos novos sistemas técnico-normativos, geralmente ocorre mais facilmente nos espaços que apresentam menores rugosidades, da mesma 
forma que encontra dificuldades nas áreas já ocupadas por divisões do trabalho pretéritas. Daí a relação quase que direta, em cada período, entre a implantação de um novo paradigma produtivo e a incorporação de uma nova área pela expansão cafeeira.

Da mesma forma que o Oeste Paulista, na passagem dos séculos XIX e XX, sucedeu a cafeicultura rudimentar praticada até então no Vale do Paraíba Fluminense e Paulista, tornando-se representativa de uma produção tecnificada, com o uso das máquinas de beneficiamento e da ferrovia, a região do sul de Minas - a partir da segunda metade do século XX -, tornou-se a principal representante da cafeicultura herdeira do paradigma da Revolução Verde e da forte regulação estatal. Mais recentemente, a partir da última década do século XX, o cerrado mineiro e, particularmente, o oeste da Bahia, tornaram-se os maiores expoentes de competitividade produtiva e do uso de sistemas técnicos informacionais vinculados à produção, na lógica neoliberal. O sul de Minas continua sendo a principal região brasileira produtora de café, contudo, as rugosidades representadas pelo relevo ondulado - que dificulta a mecanização -, e pelo predomínio de pequenas unidades produtivas têm imposto desafios para incorporar os novos sistemas técnicos produtivos e para perpetuar a atividade, sobretudo, entre os pequenos produtores, em geral descapitalizados e com reduzido acesso à informação produtiva e de mercado. Assim, conseguimos ver o papel ativo do espaço geográfico ao facilitar ou dificultar a difusão do novo, dependendo da qualidade e do acúmulo de divisões do trabalho pretéritas.

\section{Referências}

ARAÚJO FILHO, J. R. O café, riqueza paulista. Boletim Paulista de Geografia, São Paulo, n. 24, p. 75-138, out. 1956.

ARGOLLO, A. Arquitetura do café. Campinas, SP: Edunicamp; São Paulo: Imesp, 2004.

BACHA, C. J. C. Ciclos e tendências do café no Brasil. Preços Agrícolas, Piracicaba, SP, v. 10, n. 117, p. 2-5, 1996.

Evolução recente da cafeicultura mineira: determinantes e impactos. Tese (Doutorado em Economia) - Faculdade de Economia e Administração, Universidade de São Paulo, São Paulo, 1988.

BRASIL. Lei n. 4.214, de 2 de março de 1963. Dispõe sobre o Estatuto do Trabalhador Rural. Diário Oficial da União, Casa Civil, Brasília, DF, 1963.

CANO, W. Ensaios sobre a formação econômica regional do Brasil. Campinas: IE-Unicamp, 2002. 
Raízes da concentração industrial em São Paulo. Campinas, SP: IEUnicamp, 1998.

CASTILLO, R. Região competitiva e logística: expressões geográficas da produção e da circulação no período atual. In: SEMINÁRIO INTERNACIONAL SOBRE DESENVOLVIMENTO REGIONAL, 4., 2008, Santa Cruz do Sul, RS. Anais... Santa Cruz do Sul, RS: Unisc, 2008. p. 1-19. v. 1.

; FREDERICO, S. Dinâmica regional e globalização: espaços competitivos agrícolas no território brasileiro. Mercator (Online), Fortaleza, v. 9, n. 18, p. 17 26, 2010.

CATAIA, M. A. Geração de cidades e efeito modernizante da atividade agrícola no Centro-Oeste brasileiro. In: ENCONTRO DE GEÓGRAFOS DA AMÉRICA LATINA, 10., 2005, São Paulo. Anais... São Paulo: USP, 2005. p. 3297-3314.

CONSÓRCIO PESQUISA CAFÉ. Disponível em: http://www.consorciopesquisacafe. com.brl. Acesso em: 17 abr. 2017.

CONTEL, F. B. Território e finanças: técnicas, normas e topologias bancárias no Brasil. São Paulo: Annablume, 2011.

. Os sistemas de movimento do território brasileiro. In: SANTOS, M.; SILVEIRA, M. L. O Brasil: território e sociedade no início do século XXI. Rio de Janeiro: Record, 2001. p. 357-372.

DAVIRON, B.; VAGNERON, I. From commoditisation to de-commoditisation... and back again. Discussing the role of sustainability standards for agricultural products. Development Policy Review, v. 29, n. 1, 2011, p. 91-113.

DAVIRON, B.; PONTE, S. Le paradoxe du café. Paris: Quae, 2007.

DEAN, W. A ferro e fogo: a história da devastação da Mata Atlântica brasileira. São Paulo: Companhia das Letras, 1997.

DELFIM NETTO, A. O problema do café no Brasil. São Paulo: FEA-USP, 1981.

DIAS, L. C. Os sentidos da rede: notas para discussão. In: DIAS, L.; SILVEIRA, R. L. L. (Org.). Redes, sociedades e territórios. Santa Cruz do Sul, RS: Edunisc, 2005. p. 11-28. 
. Réseaux d'information et réseau urbain au Brésil. Paris: L'Harmattan, 1995.

EMBRAPA. EMPRESA BRASILEIRA DE PESQUISA AGROPECUÁRIA. Ministério da Agricultura, Pecuária e Abastecimento. Disponível em: https://www.embrapa. br/cafe. Acesso em: 17 abr. 2017.

FREDERICO, S. Globalização, competitividade e regionalização: a cafeicultura científica globalizada no território brasileiro. Geousp - espaço e tempo (Online), v. 18, n. 1, p. 55-70, 2014.

- Lógica das commodities, finanças e cafeicultura. Boletim Campineiro de Geografia, Campinas, v. 3, n. 1, p. 97-116, 2013.

. Expansão da fronteira agrícola moderna e consolidação da cafeicultura científica globalizada no oeste da Bahia. Boletim Campineiro de Geografia, Campinas, v. 2, n. 2, p. 279-301, 2012.

FURTADO, C. Formação econômica do Brasil. Rio de Janeiro: Brasiliense, 1976.

GEIGER, P. P. Evolução da rede urbana brasileira. Rio de Janeiro: CBPE, 1963.

GORZ, A. Misérias do presente, riquezas do possível. São Paulo: Annablume, 2004.

HAESBAERT, R. Gaúchos e baianos no novo nordeste: entre a globalização econômica e a reinvenção das identidades regionais. In: CASTRO, I. E.; CORREA, R. L.; GOMES, P. C. (Org.). Brasil: questões atuais sobre a organização do território. Rio de Janeiro: Bertrand Brasil, 1996. p. 362-403.

HARVEY, D. O novo imperialismo. São Paulo: Loyola, 2004.

HERREROS, M. M. A. G.; BARROS, F. G. N.; BENTES, E. S. Atividade especulativa dos fundos de investimentos no mercado futuro de commodities agrícolas (2006-2009). Revista de Política Agrícola, Brasília, DF, v. 19, n. 1, p. 24-39, 2010.

ITC. INTERNATIONAL TRADE CENTER. Annual Report, 2011. Disponível em: $\underline{\text { http:// }}$ www.intracen.org/about/annual-report/. Acesso em: 3 mar. 2012.

KAGEYAMA, A. et al (Coord.). O novo padrão agrícola brasileiro: do complexo rural aos complexos agroindustriais. In: DELGADO, G.; GASQUES, J. G.; VILLA VERDE, C. (Org.). Agricultura e políticas públicas. Brasília: IPEA, 1990. p. 113-223. 
MAZZALI, L. O processo recente de reorganização agroindustrial: do complexo à organização “em rede”. São Paulo: Edunesp, 2000.

MELLO, J. M. C. O capitalismo tardio: contribuição à revisão crítica da formação e do desenvolvimento da economia brasileira. Campinas, SP: Unicamp, 1998.

MONBEIG, P. Pioneiros e fazendeiros de São Paulo. São Paulo: Hucitec/Polis, 1984.

MORAES, A. C. R. Bases da formação territorial do Brasil: o território colonial brasileiro no "longo" século XVI. São Paulo: Hucitec, 2000.

MÜLLER, G. Complexo agroindustrial e modernização agrária. São Paulo: Hucitec, 1989.

NATAL, J. L. A. Transporte, ocupação do espaço e desenvolvimento capitalista no Brasil: história e perspectivas. Tese (Doutorado em Economia) - Instituto de Economia, Universidade Estadual de Campinas, Campinas, SP, 1991.

OIC. Organização Internacional do Café. Historical data on the global coffee trade, 2012. Disponível em: http://www.ico.org/new historical.asp. Acesso em: 25 maio 2013.

PACHECO, C. A. Café e cidades em São Paulo: um estudo de caso da urbanização na região de Araraquara e São Carlos (1880-1930). Dissertação (Mestrado em História Econômica) - Instituto de Economia, Universidade Estadual de Campinas, Campinas, SP, 1988.

PORTO-GONÇALVES, C. W. A globalização da natureza e a natureza da globalização. Rio de Janeiro: Civilização Brasileira, 2006.

PRADO JR., C. História econômica do Brasil. São Paulo: Brasiliense, 1967.

RAMOS, S. F; CASTILLO, R. A. Sistemas técnicos agrícolas do algodão e uso do território brasileiro. Revista Geografia, Rio Claro, SP, v. 35, n. 1, p. 101-114, 2010.

REINERT, E. How rich countries got rich and why poor countries stay poor. Londres: Constable, 2007.

SAES, S. M. S. A racionalidade econômica da regulamentação no mercado brasileiro de café. Tese (Doutorado em Economia) - Faculdade de Economia, Administração e Contabilidade, Universidade de São Paulo, São Paulo, 1995.

SANTOS, M.; RIBEIRO, A. C. T. O conceito de região concentrada. UFRJ/IPPUR/ 
Departamento de Geografia, 1979. [Mimeo.]

SANTOS, M.; SILVEIRA, M. L. O Brasil: território e sociedade no início do século XXI. Rio de Janeiro: Record, 2001.

SANTOS, M. Por uma outra globalização: do pensamento único à consciência universal. Rio de Janeiro: Record, 2000.

A natureza do espaço: técnica e tempo, razão e emoção. São Paulo: Hucitec, 1996.

Técnica, espaço, tempo: globalização e meio técnico-científico informacional.

3. Ed. São Paulo: Hucitec, 1994.

. Sociedade e espaço: a formação social como categoria e como método. Boletim Paulista de Geografia, São Paulo, n. 54, p. 81-100, 1977.

A cidade nos países subdesenvolvidos. Rio de Janeiro: Civilização Brasileira, 1965.

SILVA, J. G. A modernização dolorosa: estrutura agrária, fronteira agrícola e trabalhadores rurais no Brasil. Rio de Janeiro: Zahar, 1982.

SILVA, L. F. A cafeicultura brasileira no modelo tecnológico produtivista (196090). Dissertação (Mestrado em Política Científica e Tecnológica) - Instituto de Geociências, Universidade de Campinas, Campinas, SP, 1994.

SILVA, S. Expansão cafeeira e origens da indústria no Brasil. São Paulo: AlfaOmega, 1986.

SIMONDON, G. Du mode d'existence des objets techniques. Paris: Éditions Montaigne/Aubier, 1958.

SILVEIRA, M. L. Diferencias regionales en el territorio brasileño: perspectivas diacrónica y sincrónica. Scripta Nova (Online), Barcelona, v. XI, n. 244, 2007.

Uma situação geográfica: do método à metodologia. Revista Território, Rio de Janeiro, v. IV, n. 6, p. 21-28, jan./jun. 1999.

STEIN, S. Grandeza e decadência do café no vale do Paraíba. São Paulo: Brasiliense, 1961. 
SOUZA, M. C. M. Cafés sustentáveis e denominação de origem: a certificação de qualidade na diferenciação de cafés orgânicos, sombreados e solidários. Tese (Doutorado em Economia) - Faculdade de Economia, Administração e Contabilidade, Universidade de São Paulo, São Paulo, 2006.

TALBOT, J. M. Grounds for agreement: The political economy of the coffee commodity chain. Lanham-MD: Rowman and Littlefield, 2004.

TAUNAY, A. E. Pequena história do café no Brasil: 1727-1937. Rio de Janeiro: Departamento Nacional do Café, 1945.

TOPIK, S. The integration of the World Coffee Market. In: TOPIK, S.; CLARENCESMITH, W. G. The global coffee economy in Africa, Asia, and Latin America (1500-1989). New York: Cambridge University Press, 2003. p. 21-49.

VALVERDE, O. A fazenda de café escravocrata, no Brasil. Rio de Janeiro: IBC, 1970.

VIEIRA, W. Apogeu e decadência da cafeicultura fluminense (1860-1930). Dissertação (Mestrado em História Econômica) - Instituto de Economia, Universidade Estadual de Campinas, Campinas, SP, 2000. 